\title{
PERFORMANCE OF PAMONG PRAJA POLICE UNITS IN DISCIPLINING STUDENTS IN BENER MERIAH REGENCY
}

\author{
Muklir ${ }^{1)}$, Susi Diana Mustika \\ ${ }^{1}$ Program Magister Administrasi Publik FISIP Universitas Malikussaleh, muklir@unimal.ac.id
}

\begin{abstract}
Satpol PP is an element that supports the duties of the Regional Government in securing and implementing Regional Government policies that are specified in the field of public order and peace. The level of discipline of students in Bener Meriah Regency is decreasing at this time. Many students are truant and wandering around during study hours. This study aims to describe how the performance of Satpol PP in controlling students, what efforts are made to improve discipline, and how students' attitudes and behavior change after policing. This study uses a descriptive qualitative approach. The results showed that the performance of Satpol PP in controlling student discipline was good because Satpol PP always routinely patrols 8 times a month. However, there are several obstacles, such as the minimum budget and inadequate facilities and infrastructure so that the performance of Satpol PP is not optimal. The efforts made by Satpol PP to improve discipline, namely in collaboration with the Education Office and school officials, as well as socializing and providing appeals to cafe owners. Meanwhile, we found variations in changes in student attitudes and behavior.
\end{abstract}

ABSTRACT

Keywords: Performance, Satpol PP (Pamong Praja Police Unit), Ordering, Discipline, Student

\begin{abstract}
ABSTRAK
Satpol PP merupakan unsur pendukung tugas Pemerintah Daerah dalam mengamankan dan melaksanakan kebijakan Pemerintah Daerah yang bersifat khusus di bidang ketentraman dan ketertiban umum. Pada saat ini tingkat kedisiplinan pelajar di Kabupaten Bener Meriah menurun dan banyak sekali dijumpai siswa yang membolos dan berkeliaran pada saat jam belajar berlangsung. Penelitian ini bertujuan untuk mendiskripsikan bagaimana kinerja Satpol PP dalam penertiban pelajar, upaya apa saja yang dilakukan dalam meningkatkan kedisiplinan, dan bagaimana perubahan sikap dan perilaku pelajar setelah dilakukan penertiban. Penelitian ini menggunakan pendektan kualitatif deskriptif. Hasil penelitian menunjukkan bahwa kinerja Satpol PP dalam penertiban kedisiplinan pelajar sudah baik karena Satpol PP selalu rutin melakukan patroli selama 8 kali sebulan. Akan tetapi ada beberapa kendala seperti minimnya anggaran dan sarana prasarana yang belum memadai sehingga kinerja Satpol PP menjadi kurang maksimal. Adapun upaya yang dilakukan Satpol PP untuk meningkatkan kedisiplinan yaitu bekerjasama dengan Dinas Pendidikan dan pihak sekolah, serta melakukan sosialisasi dan memberikan himbauan kepada pemilik caffe dan warnet. Sedangkan untuk perubahan sikap dan perilaku pelajar sangat variatif.
\end{abstract}

Kata Kunci: Kinerja, Satpol PP, Penertiban, Pendisiplinan, Pelajar 


\section{PRELIMINARY}

The existence of Satpol PP is really needed in society. Satpol PP has the function of maintaining public order. The performance of the Satpol PP really needs to be considered by the government so that the Satpol PP can carry out their main duties and functions properly. Good performance needs to be assessed by the government. The parts that show the less than the optimal ability of Satpol PP members are identified so that strategies can be determined to improve their performance. The duties and functions of the Satpol PP as the organizer of peace and public order in the community are very significant, such as dealing with waste problems, illegal buildings, street vendors, crime, prostitution, and student discipline.

Indonesian students are not disciplined overall. Public discussed many cases of students breaking the rules. Discipline in the educational process is necessary. Discipline helps to create a strong personality for students. There are many cases of disciplinary violations by students, such as students who arrive late, leave and enter school locations arbitrarily, skip school hours, and other disciplinary actions.

The level of student discipline in Bener Meriah Regency is very low. There are still many students who roam outside the school during study hours which makes the school's image bad by the surrounding community. Therefore, the role of Satpol PP is needed in controlling undisciplined students outside the school environment. Based on the results of an interview with Mr. Handri, as the official of Satpol PP \& WH of Bener Meriah Regency, said that in once patrol there were at least 10 students or more who were absent during school hours.

Until 2018 there were 188 Satpol PP employees of Bener Meriah Regency. These data describe that the number of Satpol PP members in Bener Meriah Regency is quite large. Satpol PP has optimized the number of personnel by running 12 patrols of student control in 2016, 12 times in 2017, and 10 times in 2018. The total patrols from 2016, 2017, and 2018 were 34 times. With this number, it can be indicated that the Satpol PP performance of Bener Meriah Regency is still not effective. With this background, the researcher wants to conduct a study on the performance of Satpol PP in controlling students, what efforts are made to improve discipline, and how changes in students' attitudes and behavior after curbing are carried out.

A previous study was conducted by Milawati (2010) at the Wilayatul Hisbah office in Lhokseumawe City. The findings of the study describe the obstacles that hindered the role and

performance of Wilayatul Hisbah because the government was still half-hearted in providing budget support and other facilities so that the implementation of Islamic sharia law could not be realized as planned. Furthermore, Rosa's (2017) study shows that the government's responsiveness 
in efforts to control livestock in Lhokseumawe City is considered unsuccessful. This should be the responsibility of Satpol PP Kota Lhokseumawe. Nugrahani's study (2017) also looked at the performance of Satpol PP in Blora Regency in structuring street vendors. The results showed that the Satpol PP performance can be measured by the productivity of the organization's work in carrying out its duties, the quality of service by applying the principles of coordination, and evaluating accountability reports. The constraints experienced were the lack of Satpol PP personnel when they were about to conduct patrols and the lack of understanding of street vendors regarding the zones that are prohibited and allowed to sell.

\section{Performance in a Public Administration Perspective}

Performance is measured by achievement and output on the responsibility given to a person or agency, both in quality and quantity (Simamora, 2004; Mangkunegara, 2006). Organizational performance is related to systematic efforts to continuously improve organizational capabilities to achieve their needs effectively (Nasucha, 2004). Thus, performance is not only related to results but also related to processes (Wibowo, 2007).

Performance measures have been categorized variously by some scholars. Performance is quantitative and qualitative with indicators in the form of inputs, outputs, results, benefits, and impacts (Mahmuddin, 2005). Meanwhile, according to Dwiyanto (2006), performance indicators are measured by productivity, service quality, responsiveness, responsibility, and accountability. Abidin (2005) suggests six indicators of bureaucratic performance, namely 1) Availability of public facilities in each regional unit (rural-urban); 2) Availability of excellent, easy and cheap service;

3) The linkage between the various interests of the unit (region); 4) Environmental preservation; 5) Preservation of the bureaucracy; and 6) Integrity.

There are two main uses for performance appraisal, namely for accountability and development (Dharma, 2010). The elements used in performance appraisal according to Hasibuan (2002) include achievement, discipline, creativity, cooperation, skills, and responsibility. Soedjono (2005) added other criteria such as quality, quantity, timeliness, effectiveness, independence, and commitment.

The purpose of establishing Satpol PP is to maintain order in society. Order is essentially a condition contained in a structure or pattern that can create safe conditions (Mirdalina, 2016). In the case of students, the order is related to discipline. Discipline is a state of attitude or behavior of a person that is in accordance with the prevailing rules or regulations so that order is created (Febianti, 2015; Alimaun, 2015). Attitude is a mental disposition or state in an individual's soul 
and self to react to his environment (Koentjaraningrat in Rusmanto, 2003). Attitude consists of cognitive, affective, and conative components (Suryani, 2013).

\section{RESEARCH METHOD}

Researchers chose the research location at the Satpol PP and WH Office, located at Serule Kayu Office Complex, Simpang Tiga Redelong, Bener Meriah Regency. The reason to chose this object was that student discipline was very low. This research uses a qualitative approach. According to Moleong (2011), qualitative research is research that intends to understand the phenomena experienced by research subjects such as behavior, perception, motivation, and actions in a holistic manner. This approach is used to obtain an in-depth picture of the performance of Satpol PP and WH Bener Meriah Regency in controlling undisciplined students. The technique for determining informants is a purposive sampling (Bungin, 2007). Informants included Heads, officials, and members of Satpol PP and WH. Additional informants include the principal, teachers, and village heads in the Bener Meriah district. Data sources consist of primary data and secondary data. Data collection techniques through observation, interviews, and documentation. Data analysis techniques used the data reduction stage, data presentation, and verification (Miles \& Huberman, 1994).

\section{DISCUSSION}

\section{Satpol PP Performance in Ordering Student Discipline in Timang Gajah District}

\section{a. Productivity}

Productivity is understood as the ratio between input and output, which means a comparison of the extent to which efforts are made with the results obtained in a certain period. Productivity is one element in measuring the performance of Satpol PP of Bener Meriah Regency in controlling students as stated in the Qanun of Bener Meriah Regency Number 02 of 2018 concerning Public Order. According to the Head of Satpol PP, the number of Satpol PP personnel of Bener Meriah Regency is sufficient to support productivity as stated:

“... in Bener Meriah, the total number of field officers from Satpol PP and WH is 188 members, while the number of districts in Bener Meriah is 10. I think for now the number of 188 people distributed to 10 districts is more than enough...." (Mr. Muhammad Nasir, Serule Kayu, 02/08/2019)

Satpol PP's job is not only to curb student problems that violate discipline. However, it includes all problems that violate public order that has been regulated in the Qanun of Bener Meriah 
Regency Number 02 of 2018 concerning Public Order. The Qanun states that the Satpol PP is tasked with curbing green lines, parks and public places, orderly rivers, channels and ponds, orderly environment, orderly certain business places, orderly buildings, orderly social, orderly health, orderly education, orderly places of entertainment and crowd, orderly community participation, and orderly civil servants. The Head of Division Peace and Order of the Satpol PP Bener Meriah Regency explained:

"Currently, we have 188 field officers, consisting of 148 Satpol PP members and $40 \mathrm{WH}$ members. Our members not only curbs student indiscipline issues, but also rules all things that are deemed to violate the order set out in the Qanun...." (Mr. Handri, Serule Kayu, 02/08/2019)

However, the informant further explained that Satpol PP's performance was slightly hampered due to budget and infrastructure problems. This situation disturbs the productivity of Satpol PP members in the field. The informant said:

"Some factors that support us in carrying out our duties is the availability of budget and infrastructure. So far, our budget is very minimal, why? Because our PAD (Regional Government Income) is low, where we can't patrol without a budget... apart from a budget, our infrastructure also doesn't support us to carry out our duties. Like a patrol car, we only have 2 patrol cars, we also don't have that big Reo car... we really need infrastructure such as cars to support the implementation of our duties. If cars are not sufficient, of course it will greatly hamper all activities." (Mr. Handri, Serule Kayu, 02/08/2019)

This was confirmed by the Head of Satpol PP of Bener Meriah Regency as the following interview:

"The budget and infrastructure that support the duty of Satpol PP members in the field are very minimal and inadequate, for example, per year the Satpol PP only receives 175 million IDR... if divided by 12 months, then within 1 month our operational budget is only 14 million IDR... how will we often go to the field if the budget is low... besides infrastructure such as patrol cars, we only have 2 units, and even then a small patrol car which only holds 10 people, not a big patrol car...”. (Mr. Muhammad Nasir, Serule Kayu, 02/08/2019).

A member of the Satpol PP of Bener Meriah Regency voiced the problems they faced in the field related to these infrastructure as follow statement:

"...There are only 2 patrol cars, that is very less when compared to the number of districts in Bener Meriah Regency... because of this problem it is not surprising that many members do not participate in the policing mission." (Mr. Agus Surya Darma, Serule Kayu, 02/08/2019)

\section{b. Quality of Service}

Public satisfaction with the services provided can be used as an indicator of the work of public organizations. The main advantage of using community satisfaction as an indicator is that 
they can provide information accurately and cheaply. In disciplining students, the Satpol PP of Bener Meriah Regency provides services to stakeholders in some programs such as socialization and social control. The goal is to reduce the level of student indiscipline in Bener Meriah Regency. However, in practice, the social control approach seems to dominate. This is as explained by the following Principals:

" Until now, many of our students have been caught by the Satpol PP raids. The incident occurred because they left the school location during school times. After the students were caught, the Satpol PP brought them back to the school to be handed over to the school and given directions and punishment. However, the Satpol PP has never once conducted any socialization to this school ... it is very unfortunate because they only provide directions to students when the students have been caught in raids ... why not do the socialization to provide enlightenment so that the children discourage truancy and break the rules...." (Mr. Ponidi, SMKN 2 Bener Meriah, 03/08/2019)

"So far, the Satpol PP has never conducted outreach to our school, but when it did, our students were caught several times. A little suggestion that it is better for Satpol PP to do the socialization..." (Mr. Andi, SMPN 4 Timang Gajah, 03/08/2019)

\section{c. Responsiveness}

Responsiveness is the organization's ability to recognize community needs, formulate service agendas and priorities, and develop public service programs according to community needs and appreciation. Organizations that have low responsiveness automatically have poor performance. Regarding the problem of responsiveness, the officials of the Satpol PP Bener Meriah Regency said:

"If there are reports that many students hanging around during class hours, the Satpol PP immediately follows up on the community report.". (Mr. Muhammad Nasir, Serule Kayu, 02/08/2019)

"So far, there have been a lot of people who have reported ... if in several districts in Bener Meriah there are still a lot of students hanging around during class hours, racing, hanging out at internet cafes, hanging out in cafes etc... so that many people complained and fretted by the incident. And we also have intel in every district to help overcome community unrest because some locations are very far away from our office ... so let it be the intelligence that addresses the community's complaints to us." (Mr. Handri, Serule Kayu, 02/08/2019)

Satpol PP then followed up to respond to community reports. The actions taken by Satpol PP are still conventional in nature for every type of public report, namely conducting patrols and controlling operations. The following is a table listing public reports regarding the problems of students who do not apply discipline: 
Table 1. List of Types of Public Reports and Follow Up

\begin{tabular}{|c|l|l|l|}
\hline No & Types of Public Reports & \multicolumn{1}{|c|}{ Follow Up } & \multicolumn{1}{c|}{ Recommendation } \\
\hline 1. & $\begin{array}{l}\text { Public reports of } \\
\text { students fighting }\end{array}$ & $\begin{array}{l}- \text { Patrol } \\
- \text { Doing order }\end{array}$ & $\begin{array}{l}\text { - Scouted } \\
-\begin{array}{l}\text { Returned to their respective } \\
\text { schools }\end{array}\end{array}$ \\
\hline 2. & $\begin{array}{l}\text { Public reports that } \\
\text { students hang out at the } \\
\text { cafe during study hours }\end{array}$ & $\begin{array}{l}- \text { Patrol } \\
- \text { Doing order }\end{array}$ & $\begin{array}{l}\text { - Scouted } \\
- \text { Returned to their respective } \\
\text { schools }\end{array}$ \\
\hline 3. & $\begin{array}{l}\text { Public reports that } \\
\text { students hang out at the } \\
\text { internet cafe }\end{array}$ & $\begin{array}{l}- \text { Patrol } \\
- \text { Doing order }\end{array}$ & $\begin{array}{l}\text { - Scouted } \\
- \text { Returned to their respective } \\
\text { schools }\end{array}$ \\
\hline 4. & $\begin{array}{l}\text { Public reports there are } \\
\text { reckless students on the } \\
\text { street }\end{array}$ & $\begin{array}{l}- \text { Patrol } \\
- \text { Doing order }\end{array}$ & $\begin{array}{l}\text { Scouted } \\
- \text { Returned to their respective } \\
\text { schools }\end{array}$ \\
\hline
\end{tabular}

Source: field data, processed by the researcher, 2019

In this regard, the Principal of SMKN 2 Bener Meriah confirmed this, as he stated:

"These students of SMKN 2 Bener Meriah are among those who are often arrested by Satpol PP when they leave without bringing a permit from the school ... after being arrested, the Satpol PP immediately returned to the school because the case was simply truancy, not violating due to immoral acts. After being returned to the school, the Satpol PP gives directions, and punishment is given by the school such as making a letter of agreement and even being expelled from school". (Mr. Ponidi, SMKN 2 Bener Meriah, 03/08/2019)

\section{d. Responsibility}

Responsibility is the organization's ability to regulate the extent to which service delivery has been running by the applicable rules or regulated procedures. An interview with the Head of Division Peace and Order of the Satpol PP Bener Meriah Regency obtained the following explanation:

"In carrying out our duties we adhere to Qanun Number 02 of 2018 concerning Public Order and if in the process of controlling someone asks what is our basis for carrying out raids or controlling, we immediately explain that we are carrying out control based on what our superiors ordered and we adhere to the Qanun. In addition, the Satpol PP also has its own SOP ... so every task given is all done according to the applicable SOP at the office. The SOP regarding patrol services is clearly attached to the Decree of the Head of the Civil Service Police Unit and Wilayatul Hisbah of Bener Meriah Regency Number 65 of 2017 concerning Standard Operating Procedures at the Civil Service Police Unit and Wilayatul Hisbah of Bener Meriah Regency ... all of these have been regulated in the SOP... starting from the issue of costs / tariffs, mechanisms, the number of members in one team, up to the time frame for completion. And we always try to carry out our duties in accordance with the applicable SOPs in the office." (Mr. Handri, Serule Kayu, 02/08/2019) 
But the workload for Satpol PP, according to informants, is very large. The responsibility that is carried includes many things related to public order:

"Our programs in the field are many and all programs are in Qanun ... in that Qanun there are several programs such as orderly roads and public transportation, orderly green lines, parks and public places, orderly rivers, channels and ponds, orderly environment, orderly place, orderly building, orderly social, orderly health, orderly education, orderly places for entertainment and crowds, orderly community participation, and orderly civil servants. So we from the field of trantib do not only discipline students, but all those who violate public order. And so far we have run these programs even though they are not as optimal as possible.” (Mr. Handri, Serule Kayu, 02/08/2019)

\section{Satpol PP Efforts to Improve Student Discipline}

Controlling is carried out when there is a disorder in the rules. There is an order because there are violators. A violator is someone who does not obey the rules/regulations. Regarding the efforts made to improve discipline towards students, the Head of Division Peace and Order of the Satpol PP Bener Meriah Regency explained:

"The efforts we have made improving student discipline in Bener Meriah Regency are of course the first to routinely conduct patrols and raids, collaborate with related agencies ... we also conduct socialization to schools and finally we give an appeal to cafe owners so as not to accept students during study hours..." (Mr. Handri, Serule Kayu, 02/08/2019)

To make it clear, here is a table that lists the efforts made by the Satpol PP to improve student discipline in Bener Meriah Regency, especially in the Timang Gajah District:

Table 2. List of Efforts by Satpol PP in Improving Student Discipline in Timang Gajah District

\begin{tabular}{|c|l|l|l|}
\hline No & \multicolumn{1}{|c|}{ Activities } & \multicolumn{1}{|c|}{ Schedule } & \multicolumn{1}{c|}{ Realization } \\
\hline 1. & Carry out patrols and control & 1 week 1-3 times & In all districts \\
\hline 2. & $\begin{array}{l}\text { Conducting patrols with the Regional } \\
\text { Police }\end{array}$ & 1 month 1-3 times & In all districts \\
\hline 3. & $\begin{array}{l}\text { In collaboration with the Education } \\
\text { Office and the school }\end{array}$ & $1 \times 24$ hours & In all districts \\
\hline 4. & Socializing & Adjusted to the case findings & In all districts \\
\hline 5. & Give an appeal to cafe owners & Adjusted to the case findings & In all districts \\
\hline
\end{tabular}

Source: field data, processed by the researcher, 2019

\section{Changes in Students' Attitudes and Behaviors}

Attitudes and behavior are closely related to one another. Attitude is a response/reaction of a person to a stimulus. It will underlie the person to do something or cause behavior. The researcher interviewed the principal and teachers of SMK Negeri 2 Bener Meriah. They explained that the 
change in attitudes and behavior of students in their school after disciplinary action was taken as follows:

"From what I have seen and observed so far, the students in this school in terms of their attitudes and behavior are mediocre and indifferent, even though they have been raided many times ... why can I say that? because the student thought that for example they broke the rules and got kicked out of the school, he would be able to enter another school." (Mr. Ponidi, SMKN 2 Bener Meriah, 03/08/2019)

"At SMK Negeri 2 Bener Meriah, the students are very difficult to manage, especially since the discipline problems are very low. Maybe because in this school male students are more dominant than female students. In 2018-2019, 30\% of the students had problems at school related to the problem of indiscipline... many of them violated discipline such as truancy, smoking, skipping classes, gambling, etc. They still do this even though they have been caught by the Satpol PP and sentenced many times." (Mrs. Jurniati, SMKN 2 Bener Meriah, 03/08/2019)

A list of cases of disciplinary violations committed by students at SMK Negeri 2 Bener Meriah in 2019 is presented in the following table:

Table 3. List of Disciplinary Violation Cases at SMKN 2 Bener Meriah 2019

\begin{tabular}{|c|c|c|c|}
\hline No & Information & Amount & Follow Up \\
\hline \multirow[t]{4}{*}{1.} & Total number of students & & \\
\hline & - Male & 168 & \\
\hline & - Female & 47 & \\
\hline & Total students & 215 & \\
\hline \multirow[t]{7}{*}{2.} & Types of disciplinary offenses (case) & & \\
\hline & - Skipping classes & 45 & $\begin{array}{l}\text { Summons parents/suspended/cut } \\
\text { points }\end{array}$ \\
\hline & - Smoking & 40 & $\begin{array}{l}\text { Summons parents/suspended/cut } \\
\text { points }\end{array}$ \\
\hline & - Brawl outside school & 5 & $\begin{array}{l}\text { Summons parents/suspended/cut } \\
\text { points }\end{array}$ \\
\hline & - Nasty & 5 & $\begin{array}{l}\text { Summons parents/suspended/cut } \\
\text { points }\end{array}$ \\
\hline & - Gambling & 10 & $\begin{array}{l}\text { Summons parents/suspended/cut } \\
\text { points }\end{array}$ \\
\hline & Total cases & 105 & \\
\hline
\end{tabular}

Source: field data, processed by the researcher, 2019 
Conversely, when researchers interviewed the principal and teachers of SMP Negeri 4 Timang Gajah to find out how changes in student attitudes and behavior after receiving punishment, the following information was obtained:

"Regarding the change in attitudes and behavior of students, thank God, some are getting better but some are not able to change ... there are children who have been raided several times but are not deterred either, and some immediately change and give up for fear of being raided again.” (Mr. Andi, SMPN 4 Timang Gajah, 03/08/2019)

"I see that the students in this junior high school has changed and some are stubborn. However, more has changed for the better because the teachers in this school also instill good values in them.” (Mrs. Ratih Kumalasari, SMPN 4 Timang Gajah, 03/08/2019)

Table 4. List of Disciplinary Violation Cases at SMPN 4 Timang Gajah 2019

\begin{tabular}{|l|l|c|l|}
\hline No & \multicolumn{1}{|c|}{ Information } & Amount & \multicolumn{1}{c|}{ Follow Up } \\
\hline 1. & Total number of students & 67 & \\
\hline & - Male & 120 & \\
\hline & - Female & 187 & \\
\hline \multicolumn{3}{|c|}{ Total students } & \\
\hline 2. & Types of disciplinary offenses (case) & 20 & $\begin{array}{l}\text { Summons parents/suspended/cut } \\
\text { points }\end{array}$ \\
\hline & - Skipping classes & 10 & $\begin{array}{l}\text { Summons parents/suspended/cut } \\
\text { points }\end{array}$ \\
\hline & - Smoking & 2 & $\begin{array}{l}\text { Summons parents/suspended/cut } \\
\text { points }\end{array}$ \\
\hline & - Brawl outside school & 10 & $\begin{array}{l}\text { Summons parents/suspended/cut } \\
\text { points }\end{array}$ \\
\hline & - Nasty & 5 & $\begin{array}{l}\text { Summons parents/suspended/cut } \\
\text { points }\end{array}$ \\
\hline & - Gambling & 47 & \\
\hline
\end{tabular}

Source: field data, processed by the researcher, 2019

The researchers also triangulated the data by interviewing the Head of West Lampahan Village where the two schools are located. He said:

"I confirmed that there were students of SMK Negeri 2 Bener Meriah and SMP Negeri 4 Timang Gajah here being raided by the Satpol PP ... I saw it several times, but what I am surprised is, even though they have been raided they are still hanging around outside the school ... that's disturbing, the children were racing on the road on motorbikes with noise ... it was very disturbing and worrying. Many mothers here are afraid that their young children will be run over by them.” (Kurnia, SMPN 4 Timang Gajah, 04/08/2019) 
When the researcher interviewed one of the students of SMK Negeri 2 Bener Meriah who had been caught in the raid by the Satpol PP, he revealed the motives for skipping school as follows statement:

"The reason I skipped class was because I didn't like the lesson, sis... and there were teachers that I didn't like ... so sometimes I didn't go to the class ... then because I wanted to smoke, smoking is prohibited at school ... another one wants to eat out because I didn't like the snack school canteen.” (Restu, SMKN 2 Bener Meriah, 03/08/2019)

\section{Analysis}

Some factors that can support the performance of the Satpol PP of Bener Meriah Regency, especially in terms of disciplining student, are constrained by budgets and infrastructure, where the budget used for operational costs is insufficient to support the program to be implemented properly. Besides, facilities are also important factors that must be owned by a government agency, because facilities are anything that can be used as a means of achieving goals and everything that is the main support for the implementation of a program. Based on the results of the interview, the budget and infrastructure for the Satpol PP of Bener Meriah Regency are very minimal and inadequate. With a small budget and inadequate infrastructure, it is very difficult for Satpol PP to control society continuously. Meanwhile, the responsibility of Satpol PP is so big, not only related to student problems, but also public order issues in general.

The service quality provided by the Satpol PP of Bener Meriah Regency is still not optimal. Apart from the limited number of operations in the field, based on interviews with several school officials, information was obtained that the Satpol PP actions were only reactive in nature, there were no preventive efforts to overcome student indiscipline in the form of socialization.

The insufficient number of operations that can be carried out by Satpol PP has made the agency optimize a special strategy, namely by utilizing intel reports. According to the researchers, the existence of intelligence in each district makes it much easier for the community when they feel disturbed and restless with the behavior of students who roam and race on the road. This makes the reports submitted to the Satpol PP very credible.

In essence, the Satpol PP of Bener Meriah Regency does not only focus on curbing one problem related to public order violations but also focuses on all problems that are deemed to violate public order as listed in Qanun Bener Meriah Regency Number 02 of 2018 concerning Public Order. At this time, all Satpol PP programs listed in the Qanun have tried to run, although they have not been maximized due to several obstacles that hinder the running of these programs. According to the researchers, this shows the nature of the responsibility of Satpol PP members of 
Bener Meriah Regency because the implementation of public organization activities has been carried out in accordance with correct administrative principles and in accordance with organizational legislation. But once again, the budget and infrastructure should be provided by policymakers.

The efforts made by the Satpol PP in terms of improving student discipline, namely patrolling and policing undisciplined students. In addition, the Satpol PP also collaborated with the Bener Meriah Regency Regional Police to jointly control, in collaboration with the Bener Meriah Regency Education Office and with schools in the Bener Regency to carry out socialization to each school and provide appeals to owners' cafe so as not to accept students during study hours. These efforts are carried out with the same goal of creating discipline in the educational process in Bener Meriah Regency.

In connection with the socialization efforts carried out by Satpol PP of Bener Meriah Regency, the SMK Negeri 2 Bener Meriah and SMP Negeri 4 Timang Gajah did not justify the socialization of Satpol PP to their schools. Meanwhile, the school is a school located in Timang Gajah Subdistrict, where students are frequently raided by Satpol PP and often violate school rules. The Satpol PP only provides directions when a student has been caught or has been raided. This is different from the socialization expected by the school. According to the author, the efforts made by Satpol PP of Bener Meriah Regency have been good, but in socializing to schools it would be much better if the socialization was carried out evenly to each school and the Satpol PP should also socialize before students commit acts that violate discipline.

Changes in student attitudes and behavior after curbing varied. Some are mediocre, indifferent, and some have improved attitudes and behavior. One of the things that make students indifferent and mediocre is that they think that even though they do this action again until they are expelled from school, they can still continue their studies in another place because every child has the right to education. Besides that, there were also students who immediately changed for the better. This is closely related to other factors around it.

\section{CONCLUSION}

The Satpol PP performance in controlling student discipline in Bener Meriah Regency is good because the Satpol PP always conducts regular policing and patrols, namely 8 times a month. However, there are several obstacles faced by Satpol PP so that the Satpol PP performance is not optimal. The obstacles are the minimal budget and inadequate facilities and infrastructure. 
As for the efforts that have been made by Satpol PP of Bener Meriah Regency in improving student discipline, namely routine patrols and policing of undisciplined students. The Satpol PP also collaborates with the Bener Meriah District Police, the Bener Meriah Regency Education Office, and schools in Bener Meriah Regency. In addition, socialization activities were also held at each school and advised the cafe owners not to accept students during school times. Changes in student attitudes and behavior after the curbing are mediocre, indifferent, and some have better attitudes and behaviors.

\section{REFERENCE}

Abidin, S. Z. (2005). Dinamika Reformasi dan Revitalisasi Administrasi Publik di Indonesia. Suara Bebas.

Alimaun, I. (2015). Pengaruh Kedisiplinan terhadap Hasil Belajar Siswa Kelas V Sekolah Dasar Se-Daerah Binaan RA Kartini Kecamatan Kutoarjo Kabupaten Purworejo. Skripsi. Universitas Negeri Semarang.

Bungin, M B. (2007). Penelitian Kualitatif : Komunikasi, Ekonomi, Kebijakan Publik, dan Ilmu Sosial Lainnya. Kencana Prenada Media Group.

Dharma, S. (2010). Manajemen Kinerja. Pustaka Pelajar.

Dwiyanto, A. (2006). Reformasi Administrasi Publik. Gadjah Mada University Press.

Febianti, R. (2015). Perilaku Kedisiplinan Siswa Kelas X Selama Proses Pembelajaran Ilmu Gizi di SMK Negeri 3 Wonosari. Skripsi. Universitas Negeri Yogyakarta.

Galuh, A. N. (2017). Kinerja Satuan Polisi Pamong Praja dalam Penataan Pedagang Kaki Lima (Studi Kasus Pedagang Kaki Lima di Kabupaten Blora Perspektif Pada Perda Nomor 7 Tahun 2014 tentang Organisasi dan Tata Kerja Satuan Polisi Pamong Praja Tahun 2017). Skripsi. Universitas Muhamadiyah Surakarta.

Hasibuan, M. P. (2002). Manajemen Sumberdaya Manusia. Bumi Aksara.

Indah, R. (2016). Alternatif Kebijakan Pengelolaan Sampah (Studi di Kota Lhokseumawe). Skripsi. FISIP Universitas Malikussaleh.

Mahmuddin (2005). Manajemen Kinerja Sektor Publik. UUP AMP YKNP.

Mangkunegara, A. P. (2006). Manajemen Sumberdaya Manusia. Remaja Rosdakarya.

Milawati (2010). Peran Wilayatul Hisbah dalam Penertiban Syariat Islam (Studi pada Kota Lhokseumawe). Skripsi. FISIP Universitas Malikussaleh.

Miles, M. B. \& Huberman, M. (1994). Qualitative Data Analysis: An Expanded Sourcebook. Sage Publications, Inc

166 | Jurnal Ilmu Sosial dan Ilmu Politik Malikussaleh (JSPM) Volume 1 Nomor 2 Tahun 2020 
Mirdalina (2016). Resistensi Pedagang Kaki Lima (PKL) terhadap Penertiban Satpol PP (Studi di Pasar Bambukuning Bandar Lampung). Skripsi. FISIP Universitas Lampung.

Moleong, L. J. (2011). Metode Penelitian Kualitatif. Remaja Rosdakarya.

Nasucha, C. (2004). Reformasi Administrasi Publik: Teori dan Praktek. Grasindo.

Peraturan Pemerintah Republik Indonesia Nomor 16 Tahun 2018 tentang Satuan Polisi Pamong Praja.

Qanun Kabupaten Bener Meriah Nomor 2 Tahun 2018 tentang Ketertiban Umum

Rosa, H. T. (2017). Responsivitas Pemerintah dalam Upaya Penertiban Hewan Ternak di Kota Lhokseumawe (Studi di Kantor Satpol PP/WH Kota Lhokseumawe). Skripsi. FISIP Universitas Malikussaleh.

Rusmanto (2003). Faktor-Faktor yang Mempengaruhi Sikap dan Perilaku Masyarakat terhadap Kepatuhan Minum Obat Anti Filarial di RW II Kelurahan Pondok Asean. Skripsi. Universitas Islam Negeri Syarif Hidayatullah Jakarta.

Simamora, H. (2004). Manajemen Sumberdaya Manusia. STIE YKPN Yogyakarta.

Soedjono, S. (2005). Pengaruh Budaya Organisasi terhadap Kinerja Organisasi dan Kepuasan Kerja Karyawan pada Terminal Penumpang Umum di Surabaya. Jurnal Manajemen dan Kewirausahaan, 7(1), 22-47.

Suryani, T. (2013). Perilaku Konsumen Era Internet. Graha Ilmu.

Wibowo (2007). Manajemen Kinerja. PT. RajaGrafindo Persada. 